DE

M E D I C I N A

T R O P I C A L

$\mathrm{DE}$

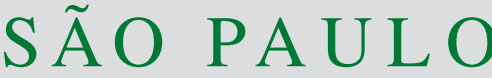

JOURNAL OF THE SÃO PAULO INSTITUTE OF TROPICAL MEDICINE

(1)Laboratorios Labin, San José, Costa Rica

(2) Universidad de Ciencias Médicas

(UCIMED), San José, Costa Rica

(3)Universidad de Costa Rica, Facultad de Microbiología, Centro de Investigación en Enfermedades Tropicales y Laboratorio de Microbiología de Alimentos, San José, Costa Rica

(4) Universidad Austral de Chile, Instituto de Microbiología Clínica, Valdivia, Región de Los Ríos, Chile

Correspondence to: María Laura Arias Echandi

Universidad de Costa Rica, Facultad de Microbiología, Centro de Investigación en Enfermedades Tropicales y Laboratorio de Microbiología de Alimentos, San José, Costa Rica

Tel: +50625118643

E-mail: maria.ariasechandi@ucr.ac.cr

Received: 31 March 2017

Accepted: 2 August 2017

\section{First isolation report of Arcobacter cryaerophilus from a human diarrhea sample in Costa Rica}

Karol Barboza1, Zaida Cubillo', Eduardo Castro², Mauricio Redondo-Solano³, Heriberto Fernández-Jaramillo ${ }^{4}$, María Laura Arias Echandi ${ }^{3}$

\section{ABSTRACT}

Arcobacter cryaerophilus is an emerging enteropathogen and potential zoonotic agent transmitted by food and water. In Costa Rica, this bacterium has not been associated with cases of human gastroenteritis, even though it has been isolated from farm animals, especially poultry. This paper reports the first isolation of A. cryaerophilus from a human case of bloody watery diarrhea and the virulence genes associated with this isolate.

KEYWORDS: Arcobacter cryaerophilus. First isolation. Chronic diarrhea.

Arcobacter cryaerophilus is an emerging enteropathogen and potential zoonotic agent that can be transmitted by food and water ${ }^{1-3}$. It is a Gram-negative curved rod recognized as a potential food and waterborne pathogen ${ }^{3}$. This bacterium was formerly known as aerotolerant Campylobacter-like bacteria ${ }^{4}$ and the Arcobacter genus was proposed by Vandamme and De Ley more than twenty years ago ${ }^{5}$. Arcobacter species have been isolated worldwide. Reports of their presence in diverse products of animal origin include poultry ${ }^{6}$, beef $^{7}$, pork $^{8}$, shellfish $^{9}$ and milk $^{10}$. Similarly, isolation from drinking and fecal polluted water has been reported ${ }^{5,10}$.

Distinct Arcobacter species can produce different pathologies in animals and humans and these bacteria are to be considered enteric pathogens according to the World Health Organization ${ }^{11}$. The ability of this group of agents to produce disease, such as human and animal enteritis has been proved. Nevertheless, there is a limited knowledge about their pathogenesis and infecting dose $\mathrm{e}^{12}$.

Four species, including A. butzleri, A. cryaerophilus, A. skirrowii and A. thereius, have been isolated from human infectious processes, especially diarrhea ${ }^{13,14}$.

Infection can occur through cross-contamination during food handling, consumption of contaminated food of animal origin, contaminated drinking water or by direct contamination with stools ${ }^{1,15,16}$.

A. butzleri, A. thereius, A. skirrowii and A. cryaerophyilus have been isolated from different animal sources in Costa Rica, especially from poultry ${ }^{17-20}$. Nevertheless, human diarrhea associated to Arcobacter sp. has not yet been described. This paper reports the first isolation of $A$. cryaerophilus from a human case of bloody watery diarrhea and the virulence genes associated with this isolate.

A 27-year-old female patient, living in the capital city and referring a previous chronic diarrhea for two months, sought a clinical laboratory because of a sudden change to a bloody watery diarrhea. She referred acute stomach pain and a diet with a strong intake of chicken meat in the last days.

The patient's stools were studied for common enteropathogens, including virus and parasites, but all tests were negative. Because of the presence of a comma-like 
rod in a smear coming from a colony isolated in blood agar aerobically cultured, and since the culture of Arcobacter is not part of common clinical microbiology laboratory routine in Costa Rica, the sample was sent to the Food and Water Microbiology Laboratory, University of Costa Rica, where the detection and identification of this microorganism was carried out. During the period of analysis, the patient did not receive any antibiotic and, when contacted again, referred to be healthy and without any further problems.

For analysis, $1 \mathrm{~g}$ of the sample was transferred into tubes containing $10 \mathrm{~mL}$ of Arcobacter enrichment broth developed by Houf that was aerobically incubated at $30{ }^{\circ} \mathrm{C}$ for $48 \mathrm{~h}^{21}$. After this time, Arcobacter isolation was performed using the membrane filtration technique ${ }^{21}$. Briefly, $100 \mathrm{~mL}$ of enrichment media were inoculated onto a sterile $0.45 \mu \mathrm{m}$ pore size nitrocellulose membrane filter placed on the surface of non-selective blood agar plates, based on the Cape Town protocol ${ }^{22}$. Plates were left at room temperature for one hour. After removing the filter, plates were aerobically incubated at $30{ }^{\circ} \mathrm{C}$ for up to 5 days. Suspicious colonies were selected, checked by Gram staining and oxidase test. Gram-negative isolates showing a positive oxidase test and a curved shape were seeded on blood agar plates in order to have a pure culture before performing PCR identification.

Arcobacter isolates were identified by PCR. DNA extraction was performed using the boiling lysis method. PCR technique described by Harmon and Wesley ${ }^{23}$ was employed for identification at the genus level. Briefly, PCR amplification was performed in a reaction mixture $(50 \mu \mathrm{L})$ containing Tris-HCl buffer $(\mathrm{pH} 7.4)$, $0.2 \mathrm{mM} \mathrm{dNTP}, 1.5 \mathrm{mM} \mathrm{MgCl}, 1 \mu \mathrm{M}$ of each primer, $1.5 \mathrm{U}$ - of $\mathrm{Taq}$ polymerase (Oxoid) and $5 \mu \mathrm{L}$ of template DNA. The Arcobacter genus-specific 16S rRNA fragment was amplified using the forward primer Arco I (5'-AGAGATTAGCCTGTATTGTATC-3') and the reverse primer Arco II (5'-TAGCATCCCCGCTTCGAATGA-3') (19). The thermocycling program was as follows: $94^{\circ} \mathrm{C}$ for $4 \mathrm{~min} ; 94^{\circ} \mathrm{C}$ for $1 \mathrm{~min}, 56^{\circ} \mathrm{C}$ for $1 \mathrm{~min}$ and $72{ }^{\circ} \mathrm{C}$ for $1 \mathrm{~min}$ ( 25 cycles); and $72{ }^{\circ} \mathrm{C}$ for $7 \mathrm{~min}$. Analysis of PCR products was done by electrophoresis $(60 \mathrm{~V}, 1.5 \mathrm{~h})$ in $1.5 \%$ agarose gels (w/v) with Mass Ruler (100-1000 bp) and GelRed staining. Positive Arcobacter identification was reported when a product of $1,223 \mathrm{bp}$ was obtained.

To differentiate Arcobacter isolates at the species level, the multiplex-PCR assay described by Douidah et $a l .{ }^{24}$ was used. Briefly, amplification of the specific fragments was done with the forward primer Arco F (5'-GCTAGAGGAAGAGAAATCAA-3') and the reverse primers ButR (5'-TCCTGATACAAGATAATTGTACG-3'), TherR (5'-GCAACCTCTTTGGCTTACGAA-3'), CibR
(5'-CGAACAGGATTCTCACCTGT-3'), and SkiR (5'-TCAGGATACCATTAAAGTTATTGATG-3') for $A$. butzleri (2,061 bp), A. thereius (1,590 bp), A. cibarius (1,125 bp), and A. skirrowii (198 bp), respectively. Amplification of the 395-bp fragment from A. cryaerophilus was done with the primers $\mathrm{CriF}$ (5'-CAGAGGAAGAGAAATCAAAT-3') and CriR (5'-CCCACTATTCCATCAGTGAG-3'). Template preparation and reaction mixture were prepared as described above. Amplification was performed using the Veriti ${ }^{\mathrm{TM}}$ 96-Well Thermal Cycler (Applied Biosystems, Foster City, USA). The thermocycling program was as follows: $94{ }^{\circ} \mathrm{C}$ for $4 \mathrm{~min} ; 94{ }^{\circ} \mathrm{C}$ for $45 \mathrm{~s}, 58{ }^{\circ} \mathrm{C}$ for $45 \mathrm{~s}$ and $72{ }^{\circ} \mathrm{C}$ for $2 \mathrm{~min}$ ( 30 cycles); and $72{ }^{\circ} \mathrm{C}$ for $7 \mathrm{~min}$. PCR products were separated by electrophoresis in $2 \%$ GelRedstained (Sigma) agarose. Gels and UV light was used for visualization. The reference strain A. butzleri $\mathrm{UACH} 001$ was used as positive control, as well as a previously identified isolate of A. cryaerophilus.

Virulence genes were identified using the protocol described by Douidah et al. ${ }^{25}$, which includes 9 different virulence genes. Primers used are described in Table 1.

PCR amplification was performed in a reaction mixture $(50 \mu \mathrm{L})$ containing Tris- $\mathrm{HCl}$ buffer ( $\mathrm{pH}$ 7.4), $0.2 \mathrm{mM}$ dNTP, $1.5 \mathrm{mM} \mathrm{MgCl}{ }_{2}, 2 \mu \mathrm{M}$ of each primer, $1.5 \mathrm{U} / \mu \mathrm{L}$ of $\mathrm{Taq}$ polymerase (Oxoid) and $2 \mu \mathrm{L}$ of template DNA.

The thermocycling program was: $94^{\circ} \mathrm{C}$ for $3 \mathrm{~min} ; 94^{\circ} \mathrm{C}$ for $145 \mathrm{~s}, 56{ }^{\circ} \mathrm{C}$ for $45 \mathrm{~s}$ and $72{ }^{\circ} \mathrm{C}$ for $45 \mathrm{~s}$. (32 cycles); and $72{ }^{\circ} \mathrm{C}$ for $3 \mathrm{~min}$. Analysis of PCR products was done by electrophoresis $(60 \mathrm{~V}, 1.5 \mathrm{~h})$ in $1.5 \%$ agarose gels $(\mathrm{w} / \mathrm{v})$ with Mass Ruler (100-1000 bp) and GelRed staining.

Isolation of Arcobacter from Costa Rican food products has been well documented. In poultry, Villalobos et al. ${ }^{17}$ reported a $17.3 \%$ frequency from chicken viscera used for human consumption and Fallas-Padilla et al. ${ }^{18}$ have reported a 56\% frequency from chicken breast samples. Also, a 6.5\% isolation frequency has been described for the whole poultry production chain. From minced meat, a $48 \%$ frequency has been reported by Córdoba et al. ${ }^{20}$. However, despite the fact that Arcobacter has been isolated from food products of animal origin in Costa Rica, there are no reports about the presence of this bacterium in stool samples from humans suffering from diarrhea.

Arcobacter has been reported as an organism associated with intestinal infections in humans since 1987, and $A$. butzleri and $A$. cryaerophilus have been associated with abortion and enteritis in animals and with diarrhea and bacteremia in adults and children ${ }^{26}$.

In this study, Arcobacter was isolated from a human stool sample of a diarrheic patient and identified as $A$. cryaerophilus. This is the first case in Costa Rica. To our knowledge, few cases of A. cryaerophilus infection have 
Table 1 - Sequence of nucleotides used as primers for detection of Arcobacter virulence genes

\begin{tabular}{|c|c|c|c|}
\hline Primer & Target gen & Sequence & Size (bp) \\
\hline cadF-F & $\mathrm{cadF}$ & TTACTCCTACACCGTAGT & 283 \\
\hline cadF-R & & AAACTATGCTAACGCTGGTT & \\
\hline ciaB-F & $\mathrm{ciaB}$ & TGGGCAGATGTGGATAGAGCTTGGA & 284 \\
\hline ciaB-R & & TAGTGCTGGTCGTCCCACATAAAG & \\
\hline cj1349-F & cj1349 & CCAGAAATCACTGGCTTTTGAG & 659 \\
\hline cj1349-R & & GGGCATAAGTTAGATGAGGTTCC & \\
\hline mviN-F & mviN & TGCACTTGTTGCAAAACGGTG & 294 \\
\hline mviN-R & & TGCTGATGGAGCTTTTACGCAAGC & \\
\hline pldA-F & pldA & TTGACGAGACAATAAGTGCAGC & 293 \\
\hline pldA-R & & CGTCTTTATCTTTGCTTTCAGGGA & \\
\hline tlyA-F & tlyA & CAAAGTCGAAACAAAGCGACTG & 230 \\
\hline tlyA-R & & TCCACCAGTGCTACTTCCTATA & \\
\hline irgA-F & $\operatorname{irg} A$ & TGCAGAGGATACTTGGAGCGTAACT & 437 \\
\hline $\operatorname{irg} A-R$ & & GTATAACCCCATTGATGAGGAGCA & \\
\hline hecA-F & hecA & GTGGAAGTACAACGATAGCAGGCTC & 537 \\
\hline hecA-R & & GTCTGTTTTAGTTGCTCTGCACTC & \\
\hline hecB-F & hecB & CTAAACTCTACAAATCGTGC & 528 \\
\hline hecB-R & & CTTTTGAGTGTTGACCTC & \\
\hline
\end{tabular}

been reported so $\mathrm{far}^{27-30}$; the latest one being reported by Figueras et al. ${ }^{30}$ in 2014 from a 26-year-old Spanish male that presented bloody diarrhea and had no comorbidities. Low incidence of human disease from A. cryaerophilus may be due to the difficulty in recognizing or identifying this bacteria, because of their slow growth rate and the use of specific multiplex PCR methods for its identification ${ }^{26,31}$.

Virulence genes are denominated as putatives due to the amino acid structures and functions corresponding to other genomic structures already characterized in other bacterial species like Campylobacter ${ }^{32}$. Nine different putative virulence genes were searched in the A. cryaerophilus strain isolated. From these, four were detected, including cadF, cj1349, plda and ciaB. The cadF and cj1349 genes encode fibronectin-binding proteins that promote the bacterial adherence to intestinal cells. The cadF also induces the bacterial internalization through the ATPase activation. The plda gene encodes an A phospholipase of the external membrane and it is also associated with reticulocyte lysis ${ }^{33}$. The ciaB gene translates invasion proteins that are injected into host cell through a T-type III secretion system and translocates virulence factors to the interior of the cell ${ }^{34}$. All these virulence genes were present in the isolate obtained from the human stool sample in Costa Rica, strongly suggesting a potential role of this organism as the causative agent of to the disease.
Earlier papers have suggested that the presence of Arcobacter species in poultry and minced meat from Costa Rica may represent a public health risk, and control measures should be developed by both industry and consumers to minimize this risk. This first isolation of $A$. cryaerophilus from a human stool sample demonstrates that virulent strains of this bacterium have the potential to colonize susceptible individuals producing diarrheal disease and should be considered during differential diagnosis of human gastroenteritis. Isolation and characterization of this bacterium might be cumbersome, but it is feasible, especially in modern times in which selective media might be used and filtration method has proved to be effective. Nevertheless, further studies are needed to establish a correlation between the presence of genes and their expression in vitro.

\section{REFERENCES}

1. Collado L, Figueras MJ. Taxonomy, epidemiology, and clinical relevance of the genus Arcobacter. Clin Microbiol Rev. 2011;24:174-92.

2. Levican A, Alkeskas A, Günter C, Forsythe SJ, Figueras MJ. Adherence to and invasion of human intestinal cells by Arcobacter species and their virulence genotypes. Appl Environ Microbiol. 2013;79:4951-7. 
3. Shah AH, Saleha AA, Zunita Z, Murugaiyah M. Arcobacter - an emerging threat to animals and animal origin food products? Trends Food Sci Technol. 2011;22:225-36

4. Merga JY, Leatherbarrow AJ, Winstanley C, Benett M, Hart CA, Miller WG, et al. Comparison of Arcobacter isolation methods, and diversity of Arcobacter spp. in Cheshire, United Kingdom. Appl Environ Microbiol. 2011;77:1646-50.

5. Vandamme P, Falsen E, Rossau R, Hoste B, Segers P, Tytgat R, et al. Revision of Campylobacter, Helicobacter and Wolinella taxonomy: emendation of generic descriptions and proposal of Arcobacter gen. nov. Int J Syst Bacteriol. 1991;41:88-103.

6. Atabay HI, Aydin F, Houf K, Sahin M, Vandamme P. The prevalence of Arcobacter spp. on chicken carcasses sold in retail markets in Turkey, and identification of the isolates using SDS-PAGE. Int J Food Microbiol. 2003;81:21-8.

7. Rivas L, Fegan N, Vanderlinde P. Isolation and characterization of Arcobacter butzleri from meat. J Food Microbiol. 2004;91:3141.

8. Van Driessche E, Houf K. Characterization of the Arcobacter contamination on Belgian pork carcasses and raw retail pork. Int J Food Microbiol. 2007;118:20-6.

9. Collado L, Guarro J, Figueras MJ. Prevalence of Arcobacter in meat and shellfish. J Food Prot. 2009;72:1102-6.

10. Collado L, Inza I, Guarro J, Figueras MJ. Presence of Arcobacter spp. in environmental water correlates with high levels of fecal pollution. Environ Microbiol. 2008;10:1635-40.

11. Phillips C. Arcobacters as emerging human foodborne pathogens. Food Control. 2001;12:1-6.

12. Lehner A, Tasara T, Stephan R. Relevant aspects of Arcobacter spp. as potential foodborne pathogen. Int J Food Microbiol. 2005;102:127-35.

13. Vandenberg O, Dediste A, Houf K, Ibekwem S, Souayah H, Cadranel S, et al. Arcobacter species in humans. Emerg Infect Dis. 2004; 10:1863-7

14. Van den Abeele A, Vogelaers D, Van Hende J, Houf K. Prevalence of Arcobacter species among humans, Belgium, 2008-2013. Emerg Infect Dis. 2014;20:1731-4

15. Wybo I, Breynaert J, Lauwers S, Lindenburg F, Houf K. Isolation of Arcobacter skirrowii from a patient with chronic diarrhea. J Clin Microbiol. 2004;42:1851-2.

16. Fera M, La Camera E, Carbone H, Malara D, Pennisi MG. Pet cats as carriers of Arcobacter spp. in Southern Italy. J Appl Microbiol. 2009;106:1661-6.

17. Villalobos EG, Jaramillo HF, Ulate CC, Echandi ML. Isolation and identification of zoonotic species of genus Arcobacter from chicken viscera obtained from retail distributors of the metropolitan area of San Jose, Costa Rica. J Food Prot. 2013;76:879-82

18. Fallas-Padilla KL, Rodríguez-Rodríguez CE, Jaramillo HF, Echandi ML. Arcobacter: comparison of isolation methods, diversity, and potential pathogenic factors in commercially retailed chicken breast meat from Costa Rica. J Food Prot. 2014;77:880-4

19. Bogantes EV, Fallas-Padilla KL, Rodríguez-Rodríguez CE, Jaramillo HF, Echandi ML. Zoonotic species of the genus Arcobacter in poultry from different regions of Costa Rica. J Food Prot. 2015;78:808-11.

20. Córdoba-Calderón O, Redondo-Solano M, Castro Arias E, Echandi ML. Arcobacter isolation from minced beef samples in Costa Rica. J Food Prot. In Press 2017.

21. Houf K, Stephan R. Isolation and characterization of the emerging foodborne pathogen Arcobacter from human stool. J Microbiol Methods. 2007;68:408-13.

22. Lastovica AJ. Non-jejuni/coli Campylobacter species and related organisms in poultry, and their relevance in human and animal disease. In: Fonseca BB, Fernández H, Rossi DA, editors. Campylobacter spp. and related organisms in poultry: pathogen-host interactions, diagnosis and epidemiology. New York: Springer; 2016. p.185-206.

23. Harmon KM, Wesley IV. Identification of Arcobacter isolates by PCR. Lett Appl Microbiol. 1996; 23: 241-244.

24. Douidah L, De Zutter L, Vandamme P, Houf K. Identification of five human and mammal associated Arcobacter species by novel Multiplex-PCR assay. J Microbiol Methods. 2010;80:281-6.

25. Douidah L, De Zutter L, Baré J, De Vos P, Vandamme P, Vandenberg $\mathrm{O}$, et al. Occurrence of putative virulence genes in arcobacter species isolated from humans and animals. J Clin Microbiol. 2012;50:735-41.

26. Fernández H, Krause S, Paz Villanueva M. Arcobacter butzleri an emerging enteropathogen: communication of two cases with chronic diarrhea. Braz J Microbiol. 2004;35:216-8.

27. Hsueh PR, Teng LJ, Yang PC, Wang SK, Chang SC, Ho SW, et al. Bacteremia caused by Arcobacter cryaerophilus 1B. J Clin Microbiol. 1997;35:489-91.

28. Tee W, Baird R, Dyall-Smith M, Dwyner B. Campylobacter cryaerophila isolated from a human. J Clin Microbiol. 1988;26:2469-73.

29. Woo PC, Chong KT, Leung K, Que T, Yuen K. Identification of Arcobacter cryaerophilus isolated from a traffic accident victim with bacteremia by $16 \mathrm{~S}$ ribosomal RNA gene sequencing. Diagn Microbiol Infect Dis. 2001;40:125-7.

30. Figueras MJ, Levican A, Pujol I, Ballester F, Rabada Quilez MJ, Gomez-Bertomeu F. A severe case of persistent diarrhea associated with Arcobacter cryaerophilus but attributed to Campylobacter sp. and a review of the clinical incidence of Arcobacter spp. New Microbes New Infect. 2014;2:31-7.

31. Kayman T, Atabay HI, Abay S, Hizlisoy H, Molva C, Aydin F. Human acute gastroenteritis with Arcobacter butzleri. Clin Microbiol Newsletter. 2012;34:197-9.

32. Douidah L, de Zutter L, Baré J, De Vos P, Vandamme P, Vandenberg $\mathrm{O}$, et al. Occurrence of putative virulence genes 
in arcobacter species isolated from humans and animals. J Clin Microbiol. 2012;50:735-41.

33. Tabatabaei M, Shirzad Aski H, Shayegh H, Khoshbakht R. Occurrence of six virulence-associated genes in Arcobacter species isolated from various sources in Shiraz, Southern Iran. Microb Pathog. 2014;66:1-4.
34. Iraola G, Pérez R, Naya H, Paolicchi F, Pastor E, Valenzuela S, et al. Genomic evidences for the emergence and evolution of pathogenicity and niche preferences in the genus Campylobacter. Genome Biol Evol. 2014;6:2392-405. 